\title{
TINJAUAN PROSES PENGOLAHAN AIR BAKU (RAW WATER) MENJADI AIR BERSIH PADA SARANA PENYEDIAAN AIR MINUM (SPAM) KECAMATAN RANGSANG KABUPATEN KEPULAUAN MERANTI
}

\author{
Harmiyati $^{1}$ \\ ${ }^{1}$ Dosen Program Studi Teknik Sipil, Universitas Islam Riau \\ Jalan Kaharuddin Nasution No. 113 Perhentian Marpoyan Pekanbaru 28284
}

\begin{abstract}
ABSTRAK
Di kabupaten Kepulauan Meranti khususnya Masyarakat Kecamatan Rangsang pada umumnya menggunakan air hujan dan air Sungai sebagai kebutuhan air bersih sehari-hari, jika pada musim kemarau masyarakat pada umumnya sulit mendapatkan air bersih. Dengan adanya Sarana penyediaan air bersih yang dibangun oleh pemerintahan Kabupaten Kepulauan Meranti yaitu Sarana Penyediaan Air Minum (SPAM) ini sangat membantu dalam memenuhi kebutuhan air bersih masyarakat. Dilihat secara warna, air bersih yang di produksi oleh SPAM Kecamatan Rangsang berwarna kecoklatan, dilihat dari segi warna hampir sama dengan air baku SPAM Kecamatan Rangsang tersebut.
\end{abstract}

Pada SPAM Kecamatan Rangsang ini proses pengolahan air bersih menggunakan metode koagulasi, flokulasi, sedimentasi dan filtrasi. Peneliti mencoba meninjau apakah proses-proses pengolahannya telah sesuai dengan metode yang telah di terapkan, mengetahui kualitas air bersih yang dihasilkan serta mengetahui masalah-masalah yang terdapat pada SPAM Kecamatan Rangsang tersebut.

Dari hasil penelitian yang dilakukan untuk pemprosesan air bersih adanya proses yang tidak dilakukan yaitu tidak dilakukan pembubuhan zat Koagulan, hal tersebut dikarenakan zat-zat Koagulan yang ada di SPAM Kecamatan Rangsang tidak tersedia untuk saat ini. Untuk kualitas air bersih yang di produksi SPAM Kecamatan Rangsang tidak memenuhi standar kualitas air bersih berdasarkan peraturan menteri kesehatan nomor 416 tahun 1990 tentang "syarat-syarat dan pengawasan kualitas air" yaitu air bersih sesuai dengan hasil uji laboratorium dinas kesahatan kota pekanbaru pada tanggal 13 November 2017, serta terdapat beberapa alat yang tidak beroperasi, yaitu rusaknya 1 buah pompa Intake dan 1 buah pompa distribusi

Kata Kunci : Air Bersih, Intake, Koagulan, SPAM Kecamatan Rangsang. 


\section{PENDAHULUAN}

\subsection{Latar Belakang}

Air bersih menjadi suatu kebutuhan manusia yang sangat penting dalam kehidupan sehari-hari, baik itu kebutuhan rumah tangga maupun non rumah tangga. Begitu juga dengan seluruh makhluk hidup yang ada di bumi ini sangat membutuhkan adanya air bersih. Dalam pemenuhan air bersih tersebut manusia melakukan berbagai upaya untuk mendapatkannya. Sumber air untuk kebutuhan hidup bisa didapat dari air tanah, air hujan dan air permukaan, namun sumber air tersebut tidak bisa langsung digunakan apalagi untuk dikonsumsi perlu adanya proses pengolahan air terlebih dahulu

$\begin{array}{lcr}\text { Di kabupaten } & \text { Kepulauan } & \text { Meranti } \\ \text { khususnya } & \text { Masyarakat } & \text { desa } \\ \text { Kecamatan } & \text { Rangsang } & \text { pada }\end{array}$ umumnya menggunakan air hujan dan air Sungai sebagai kebutuhan air bersih sehari-hari, jika pada musim kemarau masyarakat pada umumnya sulit mendapatkan air bersih. Dengan adanya Sarana perasaranaan penyediaan air bersih yang dibangun oleh pemerintahan Kabupaten Kepulauan Meranti yaitu Sarana Penyediaan Air Minum (SPAM) ini sangat membantu dalam memenuhi kebutuhan air bersih masyarakat. Pemerintah yang mengelola, mengontrol dan menyalurkan air kerumah-rumah. Air baku yang diambil berasal dari air sungai Atlas yang airnya berwarna kecoklatan, yang diolah dan diproses hingga menghasilkan air bersih dan didistribusikan melalui sistem perpipaan sampai ke konsumen.

Dilihat dari tingkat perkembangan atau pertumbuhan penduduk harus disertai dengan perkembangan infrastruktur sarana dan perasaranaan yang memadai, seperti sarana penyediaan air bersih, harus dapat beroperasi secara maksimal, maka dari itu peneliti perlu adanya tinjauan pada unit pengolahan air bersih dan proses pengolahan airnya agar dapat mengetahui apakah kebutuhan air bersih masyarakat dapat terpenuhi untuk massa sekarang maupun masa yang akan datang.

\subsection{Rumusan Masalah}

Adapun yang menjadi masalah dalam penelitian ini adalah :

1. Bagaimana mekanisme dan alur pemprosesan air bersih pada SPAM Kecamatan Rangsang kabupaten Kepulauan Meranti.

2. Berapa besarnya tingkat pertumbuhan penduduk dan kebutuhan air bersih 10 (sepuluh) tahun kedepan, mulai dari tahun 2017 hingga tahun 2026.

3. Apakah kapasitas pompa intake dan pompa distribusi yang terdapat pada SPAM Kecamatan Rangsang mampu memenuhi air bersih masyarakat Desa Setempat.

\subsection{Tujuan Penelitaian}

Tujuan dari penelitian ini adalah :

1. Menganalisa mekanisme atau alur pemprosesan air bersih pada SPAM Kecamatan Rangsang Kabupaten Kepulauan Meranti.

2. Mengetahui tingkat pertumbuhan penduduk dan besarnya tingkat kebutuhan air bersih 10 (sepuluh) tahun kedepan, mulai dari tahun 2017 hingga tahun 2026.

3. Menentukan kapasitas pompa intake dan pompa 
distribusi yang terdapat pada SPAM Kecamatan Rangsang Kabupaten Kepulauan Meranti.

\subsection{Manfaat Penelitian}

Manfaat dari hasil penelitian ini adalah sebagai berikut :

1. Bagi Peneliti dapat mengetahui serta memahami mekanisme pemprosesan air baku menjadi air bersih pada SPAM Kecamatan Rangsang Kabupaten Kepulauan Meranti.

2. Bagi pihak SPAM Kecamatan Rangsang Kabupaten Kepulauan Meranti. sebagai masukan, mengoptimalisasikan pelayanan air bersih terhadap masyarakat Desa Kecamatan Rangsang Kabupaten Kepulaun Meranti.

\subsection{Batasan Masalah}

Dalam penelitian ini Penulis memberikan batasan masalah agar penelitian ini lebih terarah dan pembahasan tidak keluar dari konteks penelitian.

1. Menganalisa pemprosesan dimulai dari penyadapan air baku sampai menjadi air bersih.

2. Perhitungan proyeksi hanya untuk mengetahui jumlah penduduk dan kebutuhan air bersih 10 (sepuluh) tahun ke depan, mulai dari tahun 2017 hingga tahun 2026.

3. Perhitungan pompa berdasarkan pada pompapompa utama yang terdapat di SPAM Kecamatan Rangsang Kabupaten Kepulauan Meranti yaitu pompa intake dan pompa distribusi.

\section{LANDASAN TEORI}

\section{Standar Kualitas Air Baku}

Dengan berlakunya baku mutu air untuk badan air, air limbah dan air bersih, maka dapat dilakukan penilaian kualitas air untuk berbagai kebutuhan. Di Indonesia ketentuan mengenai standar kualitas air bersih mengacu pada Peraturan Menteri Kesehatan berdasarkan Peraturan Pemerintah No. 416 tahun 1990 tentang Syarat-Syarat dan Pengawasan Kualitas Air Bersih. Berdasarkan SK Menteri Kesehatan 1990 Kriteria penentuan standar baku mutu air dibagi dalam tiga bagian yaitu:

1. Persyaratan kualitas air untuk air minum.

2. Persyaratan kualitas air untuk air bersih.

3. Persyaratan kualitas air untuk limbah cair bagi kegiatan yang telah beroperasi.

Sistem penyedian air bersih harus memenuhi syarat mutu atau kualitas dari air baku air bersih. Maka Menteri Kesehatan mengeluarkan peraturan berupa Persyaratan kualitas air bersih yang tercantum dalam peraturan Menteri Kesehatan ini meliputi persyaratan fisik, persyaratan kimia, persyaratan biologis dan persyaratan radiologis. Syarat-syarat tersebut berdasarkan Permenkes416/Menkes/PER/IX/1990 dinyatakan bahwa persyaratan kualitas air bersih adalah sebagai berikut :

1. Syarat-syarat fisik

Secara fisik air bersih harus jernih, tidak berbau dan tidak berasa. Selain itu juga suhu air bersih sebaiknya sama dengan 
suhu udara atau kurang lebih $25^{\circ} \mathrm{c}$, dan apabila terjadi perbedaan maka batas yang diperbolehkan adalah $25^{\circ} \mathrm{c} \pm$ $30^{\circ} \mathrm{c}$.

2. Syarat-syarat kimia

Air bersih tidak boleh mengandung bahan-bahan kimia dalam jumlah yang melampaui batas. Beberapa persyaratan kimia antara lain adalah : $\mathrm{pH}$, total solid, zat organik, $\mathrm{CO}_{2} \quad$ agresif, kesadahan, kalsium $(\mathrm{Ca})$, besi $(\mathrm{Fe})$, mangan $(\mathrm{Mn})$, tembaga $(\mathrm{Cu})$, seng $(\mathrm{Zn})$, chlorida $(\mathrm{Cl})$, nitrit, flourida $(\mathrm{F})$, serta logam berat.

3. Syarat-syarat bakteriologis dan mikrobiologis.

Air bersih tidak boleh mengandung kuman patogen dan parasitik yang mengganggu kesehatan. Persyaratan bakteriologis ini ditandai dengan tidak adanya bakteri E coli atau Fecal coli dalam air.

4. Syarat-syarat radiologis

Persyaratan radiologis mensyaratkan bahwa air bersih tidak boleh mengandung zat yang menghasilkan bahanbahan yang mengandung radioaktif, seperti sinar alfa, beta dan gamma.

\section{Proses Pengolahan Air Baku}

Pada umumnya instalasi pengolahan air minum merupakan suatu sistem yang mengkombinasikan proses filtrasi, sedimentasi, koagulasi, dan mikro biologi. Tujuan dari sistem pengolahan air minum yang sesuai dengan standar kualitas kuantitas dan kontinuitas. Tingkat pengolahan air tergantung pada karakteristik sumber air baku yang digunakan, sumber air baku yang digunakan berasal dari air permukaan, air permukaan cenderung memiliki kekeruhan yang cukup tinggi dan adanya kemungkinan terkontaminasi mikroba yang lebih besar. Untuk pengolahan air baku yang berasal dari permukaan ini, unit filtrasi hampir selalu diperlukan (Kusnaedi, 2006 ).

\section{Proses Pengolahan Air Dengan Cara Filtrasi}

Penyaringan merupakan proses pemisahan antara padatan atau koloid dengan cairan. Proses penyaringan merupakan proses awal (primary treatment). Bahan padatan pada umumnya dapat dilihat secara langsung seperti potongan kayu potongan benda-benda lainnya. Bahan padatan dapat disaring secara kasar atau sedang melalui proses awal (primary treatmen). Apabila air baku yang akan disaring berupa air yang mengandung butiran halus atau bahan-bahan yang larut maka sebelum proses penyaringan sebaiknya dilakukan proses koagulasi atau netralisasi terlebih dahulu yang menghasilkan endapan. Dengan demikian bahan-bahan tersebut dapat dipisahkan dari cairan melalui filtrasi. Menurut tipenya saringan dapat dibedakan menjadi tiga yaitu (Kusnaedi, 2006) :

1. Singgle medium yaitu saringan untuk menyaring air yang mengandung

padatan dengan ukuran seragam.

2. Dual medium yaitu saringan yang menyaring air limbah yang didominasi oleh ukuran pemadatan.

3. Three medium yaitu saringan yang menyaring air limbah yang mengandung ukuran padatan dengan ukuran beragam. 


\section{Proses Pengolahan Air Baku Dengan Cara Sedimentasi}

Sedimentasi merupakan proses pemurnian air dengan cara pengendapan bahan padat yang terdapat dalam air baku. Proses sedimentasi bisa menjadi zat yang terlarut didalam air baku memiliki masa yang lebih berat dari masa air baku. Sehingga dengan sendirinya zat yang terlarut didalam air baku akan mengendap dan terpisah dari air. (Sutrisno dkk, 2002)

Proses pengendapan ada yang bisa terjadi langsung tetapi ada pula yang memerlukan proses pendahuluan seperti koagulasi atau reaksi kimia. Prinsip sedimentasi adalah pemisahan bagian padat dengan memanfaatkan gaya gravitasi sehingga bagian yang padat dan memiliki masa yang lebih berat dari air berada didasar kolam pengendapan sedangkan air akan berada diatasnya. Contoh dari pemurnian air dengan cara sedimentasi adalah pasir dan batu kecil yang terangkut kedalam kolam pengendapan dengan sendirinya akan tenggelam kedasar kolam dan terpisah dari air. Begitu juga halnya dengan pertikel-pertikel lain dengan masa yang lebih berat dari air yang terlarut didalam air baku dengan sendirinya akan mengalami sedimentasi. Sedangkan jika masa suatu benda atau partikel yang terlarut kedalam air baku semakin mendekati dengan masa air maka proses sedimentasi akan semakin lambat.

Pengendapan dapat dibedakan menjadi 4 bagian (Kawamura, 1991 dalam Juliana, 2016) :

1. Pengendapan tipe 1 adalah (Free Settling)
Pengendapan tipe 1 adalah pengendapan dari partikelpartikel siskrit yang bukan merupakan flok. Contoh dari pengendapan tipe 1 adalah pengendapan benda pasir, batu halus, dan lainnya bukan merupakan hasil dari flokuasi. Material ini bisanya terbawa oleh pompa air baku atau pompa intake.

2. Pengendapan tipe 2 (Flocculentsetting)

Pengendapan tipe 2 adalah pengendapan yang merupakan partikel-pertikel yang berupa flok pada suatu spensi. Flok bisa terjadi karena adanya pencampuran zat-zat koagulasi dengan air yang memiliki kadar asam atau kekeruhan (Turbidity).

3. Pengendapan tipe 3 (Zone Hindred Settling)

Pengendapan ini adalah pengendapan dari pertikel dengan kosentrasi sedang, partikel-partikel tersebut sangat berdekatan sehingga gaya antar partikel mencegah terjadinya pengendapan dari pertikel sekelilingnya. Partikel-partikel tersebut berada pada posisi yang tetap satu sama lain dan semua mengendap dengan kecepatan konstan.

4. Pengendapan tipe 4 (Copression Settling)

Pengendapan ini adalah pengendapan dari pertikel yang memiliki kosentrasi tinggi dimana partikel saling bersentuhan satu sama lainnya dan pengendapan hanya bisa terjadi dengan cara melakukan kompresi terhadap masa tersebut. 


\section{Pengolahan Air Dengan Cara Koagulasi}

Koagulasi adalah proses pengolahan air dengan menggunakan sistem pengadukan cepat sehingga dapat mereaksikan bahan kimia (koagulan) secara seragam. Pada dasarnya proses koagulasi dapat dilakukan dengan penambahan bahan kimia kedalam air agar kotoran dalam air yang berupa padatan tersuspensi, misalnya zat warna organik, lumpur halus bakteri dan lain-lain dapat menggumpal dan cepat mengendap. Pada proses koagulasi ini yang banyak digunakan adalah kapur, tawas, dan kaporit. Banyaknya koagulan tergantung pada jenis dan kosentrasi ion-ion yang larut dalam air baku. Untuk mempercepat proses koagulasi dalam air baku sebaiknya dilakukan pengadukan dengan mixer statis maupun rapid mixer (Sutrisno dkk, 2002).

\section{Pengolahan Air Dengan Cara Mikro Biologi.}

Upaya memperbaiki mikro biologi air yang paling konvensional dan paling sering dilakukan oleh masyarakat banyak adalah dengan cara mematikan mikro organisme yang ada didalam air. Proses ini bisa dilakukan sekaligus dengan proses koagulasi ataupun praktek sederhana dengan cara mendidihkan air baku mencapai suhu $100^{\circ} \mathrm{C}$. Pengolahan air sangat membutuhakan ketepatan dalam pemerosesannya. Semakin komplek keadaan air baku yang akan diolah maka proses pengolahannya pun semakin teliti dan tepat dalam menggunakan alat dan bahan dalam pemurnian air tersebut (Kawamura, 1991 dalam Juliana, 2016).

\section{METODE PENELITIAN}

\section{Lokasi Penelitian}

Lokasi Penelitian ini dilakukan di SPAM Kecamatan Rangsang yang berada di Desa Wonosari Jalan Sidodadi Kecamatan Rangsang Kabupaten Kepulauan Meranti. Untuk lebih jelasnya dapat dilihat pada gambar denah lokasi.

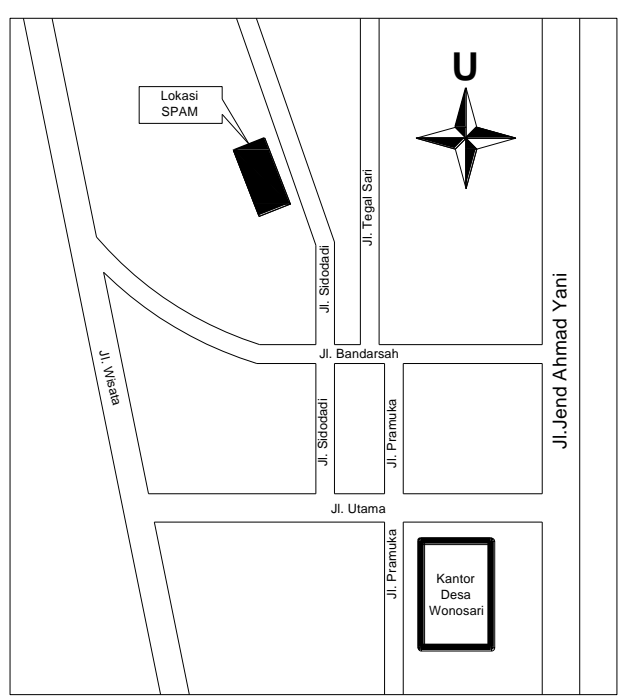

Gambar 4.1 Denah Lokasi

Pengolahan SPAM Kecamatan Rangsang

\subsection{Teknik Penelitian}

Untuk menganalisis dan menyelesaikan penelitian ini peneliti meggunakan metode Observasi dan Experiment,Peneliti menggumpulkan data-data dilapangan berdasarkan hasil tinjauan dilapangan, yaitu

Data sekunder berupa data laporan hasil uji laboratorium SPAM Kecamatan Rangsang, serta data laporan hasil uji laboratorium dinas kesehatan kota Pekanbaru. 


\subsection{Tahapan Penelitian}

Tahapan penelitian merupakan tahap-tahap yang dilakukan secara berurutan selama berlangsungnya penelitian. Tahapan-tahapan ini memberikan gambaran secara garis besar langkah-langkah pelaksanaan penelitian yang akan menuntun peneliti agar lebih terarah selama berjalannya penelitian. Berikut ini adalah tahap-tahap yang dilakukan selama penelitian, yaitu:

1. Mulai

2. Persiapan

Dalam pelaksanaan penelitian harus dengan persiapan yang matang agar penelitian untuk pembuatan tugas akhir ini dapat dilakukan secara benar dan efektif. Adapun persiapan yang dilakukan dalam penelitian ini antara lain:
a. Pengurusan surat izin pengantar untuk pengumpulan data-data di lapangan.
b. Menetapkan waktu dan lamanya pelaksanaan survey.

3. Pengumpulan Data

Pada tahap ini, Data sekunder didapat dari kantor SPAM Kecamatan Rangsang yaitu data mengenai hasil uji kualitas air.

4. Analisa Data

Data-data yang telah dikumpulkan dianalisa dengan beberapa langkah sebagai berikut:
a. Menganalisis proses pengolahan air baku menjadi air bersih dengan peraturan yang ada.
b. Membandingkan hasil kualitas air dengan data laboratorium.

5. Hasil dan Pembahasan

Hasil yang didapat dari tinjauan pemprosesan sabagai acuan hasil akhir yang dianalisa.

\section{Kesimpulan dan Saran}

Membuat suatu kesimpulan hasil akhir analisa dan dapat memberikan saran terhadap hasil penelitian.

Untuk mengetahui langkah-langkah pekerjaan dalam penelitian ini digunakan bagan alir penelitian, yang dapat dilihat pada Gambar 4.3

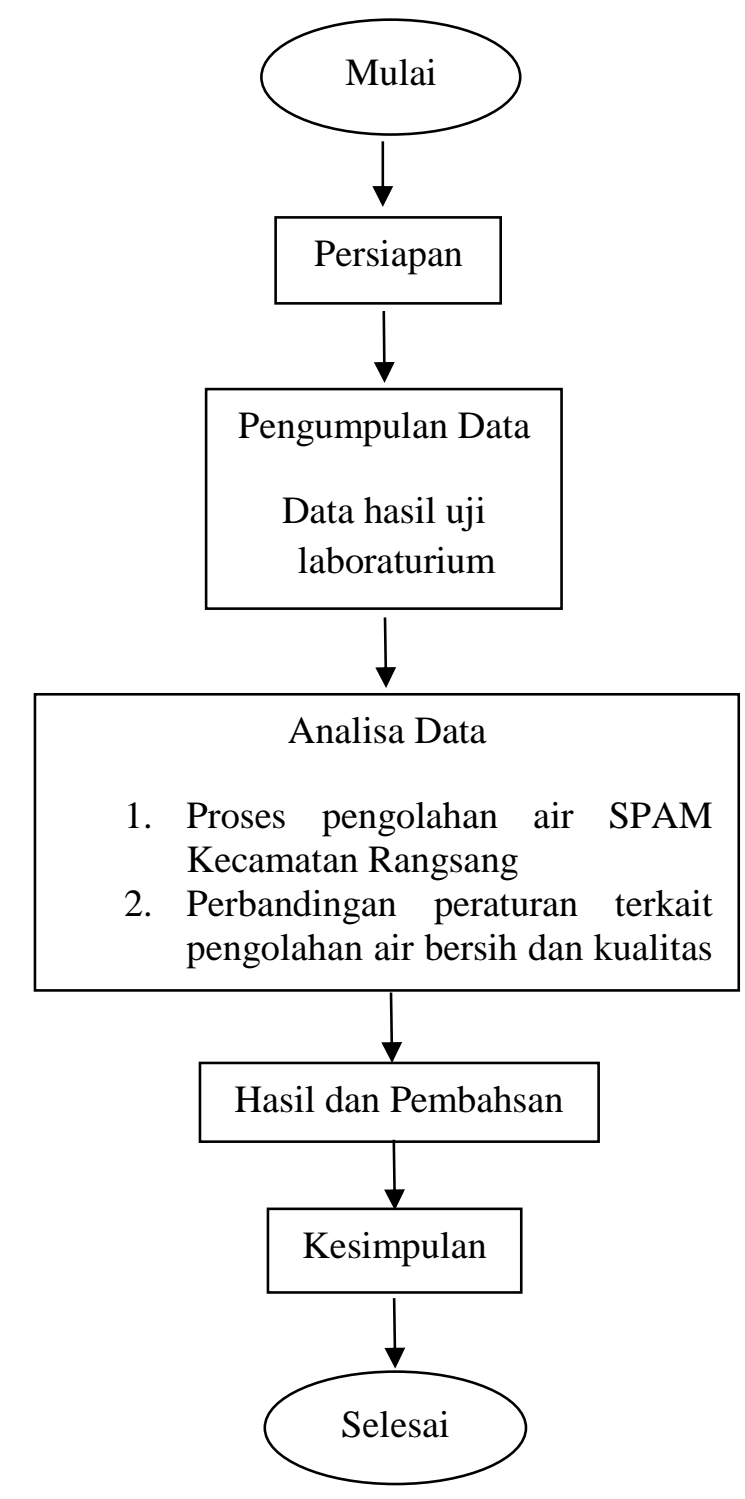

Gambar 4.2 Bagan Alir Penelitian 
HASIL DAN PEMBAHASAN Skema Pemprosesan Air baku (Raw Water) Menjadi Air Bersih

Untuk proses pengolahan air baku menjadi air bersih terdapat banyak cara untuk melakukan pengolahan air untuk menjadikan suatu air bersih, antara lain, dengan cara Filtrasi, sedimentasi,koagulasi, mikro biologi dan lain-lain.

Berikut adalah skema sistem pengolahan air bersih pada SPAM Kecamatan Rangsang.

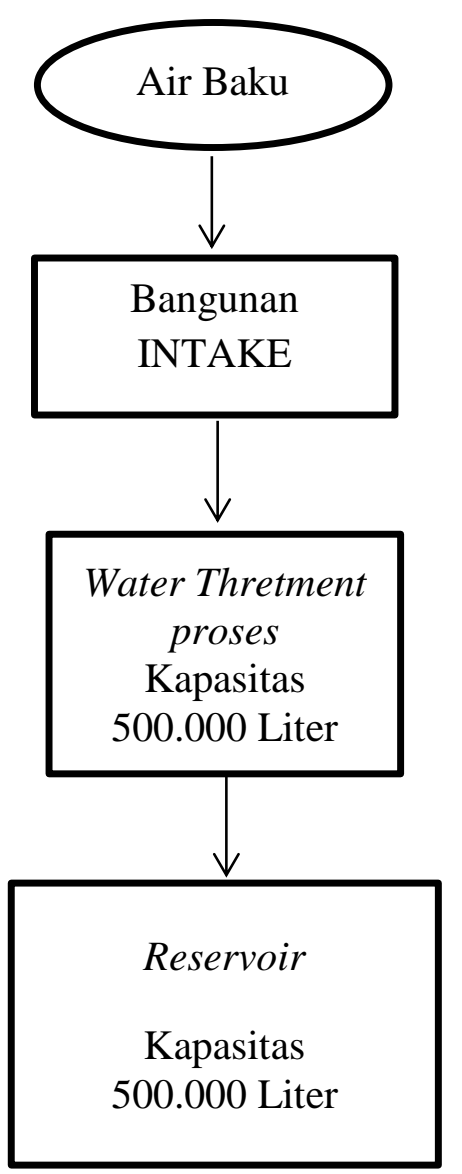

Gambar 5.1 Skema Pemerosesan Air Bersih SPAM Kecamatan Rangsang

\subsection{Raw water Intake (Penyadapan Air Baku)}

Sumber air baku SPAM Kecamatan Rangsang berasal dari Sungai Atlas, lokasi intake terletak di pinggir sungai Atlas tersebut. Air baku diambil dari Sungai Atlas ini dengan menggunakan 2 buah Pompa intake jenis Submersible dengan kapasitas pemompaan 20 liter/detik. Untuk saat ini pompa intake yang berfungsi hanya 1 pompa saja, dikarenakan pompa intake yang lainnya mengalami kerusakan.

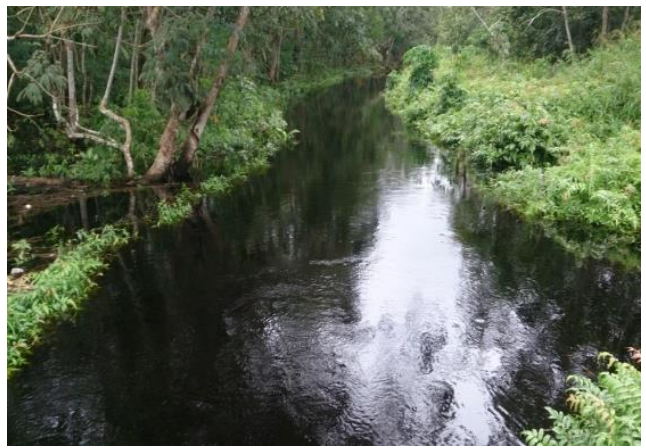

Gambar 5.2 Sumber air baku SPAM Kecamatan Rangsang

(Dokumentasi Lapangan)

Air dari sungai Atlas ini kemudian di salurkan melalui sistem perpipaan menuju bak instalasi pengolahan air (IPA) untuk melakukan proses pengolahan. Untuk proses penyaluran dari pipa intake menuju bak instalasi pengolahan menggunakan pipa Galvanis yang berukuran 6 inch.

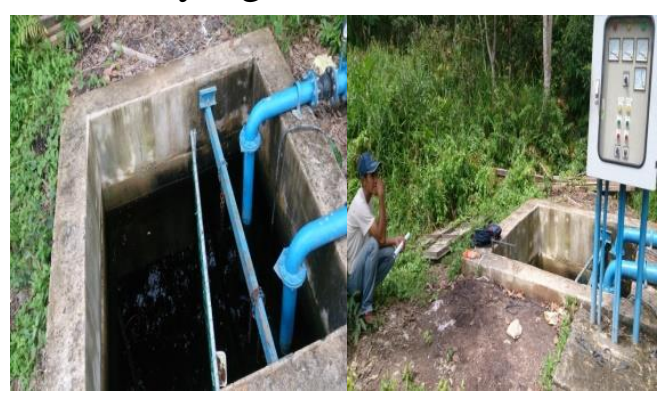

Gambar 5.3 intake air baku (Dokumentasi Lapangan) 


\subsection{Bangunan Water Treatment Process (WTP) / Instalasi pengolahan air (IPA)}

Water Treatment Process (WTP) adalah bangunan proses pengolahan air baku menjadi air bersih, Di dalam bangunan proses pengolahan air terjadi proses koagulasi, flokulasi, sedimentasi, dan proses filtrasi. Setelah mengalami proses-proses tersebut maka barulah terjadinya air bersih. Pada SPAM Kecamatan Rangsang ini untuk proses pengolahan air bersih prosesnya terjadi di dalam satu bangunan atau Bak saja dengan sistem pengaliran air secara paralel, yang memiliki volume bangunan $500 \mathrm{~m}^{3}$.

\subsubsection{Bak pengumpul air baku}

Air yang dipompa oleh pompa Intake akan langsung masuk kedalam bak pengumpul air baku. Bak pengumpul air baku ini lebih tinggi $0,5 \mathrm{~m}$ dari ketinggian bangunan Water treatment proses.

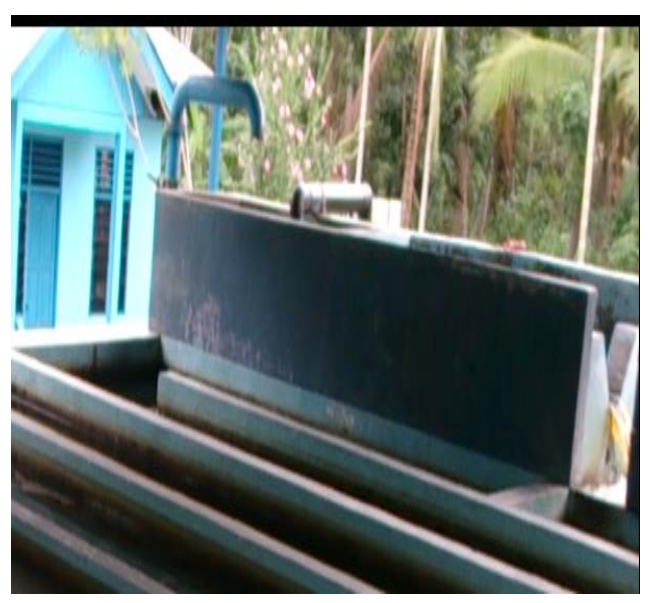

Gambar 5.6 Bak Pengumpul Air Baku

\subsubsection{Bak Koagulasi}

Bak Koagulasi adalah suatu wadah yang berfungsi untuk mencampurkan zat koagulan pada proses pengolahan air, proses ini terjadi penstabilan partikel koloid dengan bahan kimia atau zat koagulan sehingga partikel koloid bergabung menjadi gumpalangumpalan kecil pada air. Pada SPAM Kecamatan Rangsang ini zat Koagulan menggunakan alauminium sulfate, kaporit, polimer, dan soda ash. untuk takaran zat-zat Koagulan tersebut yaitu, alauminium sulfate $50 \mathrm{~kg}$, kaporit $5 \mathrm{~kg}$, polimer 5 ons dan soda Ash $30 \mathrm{~kg}$ untuk takaran sekali produksi per 500.000 liter air, untuk takaran tersebut berdasarkan jar test yang dilakukan oleh pihak SPAM Kecamatan Rangsang.

Air yang keluar dari saluran pada bak pengumpul akan langsung tercampur dengan zat koagulan, sebelum air masuk ke bak pengumpul terjadi proses injeksi zat koagulan pada pipa distribusi dari Intake ke bak pengumpul. Proses injeksi zat koagulan tersebut dilakukan dari rumah kimia, pada rumah kimia inilah zat-zat koagulan tersebut di proses sebelum di injeksi ke pipa distribusi tersebut.

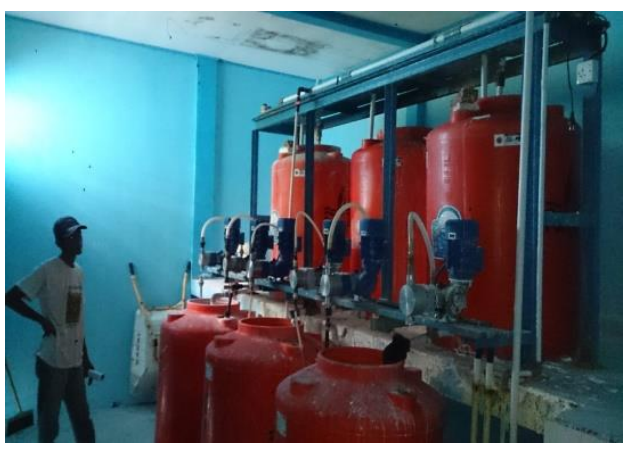

Gambar 5.7 Rumah Kimia, Proses pengadukan Zat Koagulan (Dokumentasi Lapangan)

Untuk proses zat koagulan pada saat ini tidak dilakukan pada SPAM Kecamatan Rangsang ini, dikarenakan bahan-bahan untuk proses pembubuhan saat ini tidak tersedia, pemerintah kabupaten 
kepulauan Meranti saat ini belum bisa menganggarkan untuk pembelian bahan kimia tersebut.

\subsubsection{Bak Flokulasi}

$A$ ir yang telah mengalami proses koagulasi akan mengalir ke bak flokulasi pada proses flokulasi akan terbentuk gumpalan-gumpalan atau flok yang semakin banyak. gumpalan-gumpalan atau flok tersebut saling mengikat sehingga dapat dilihat dengan kasat mata pada air. Akan tetapi pada SPAM Kecamatan Rangsang ini belum adanya perubahan bentuk air, hal ini di karenakan proses koagulasi sebelumnya tidak berjalan dengan baik, dikarenakan tidak adanya pembubuhan zat-zat kimia pada proses sebelumnya, sedangkan zatzat kimia itulah yang membantu proses pemisahan air dengan kotoran pada air terebut. untuk proses penggolahan yang terdahulu pada proses ini sudah mulai terlihat perubahan pada airnya.

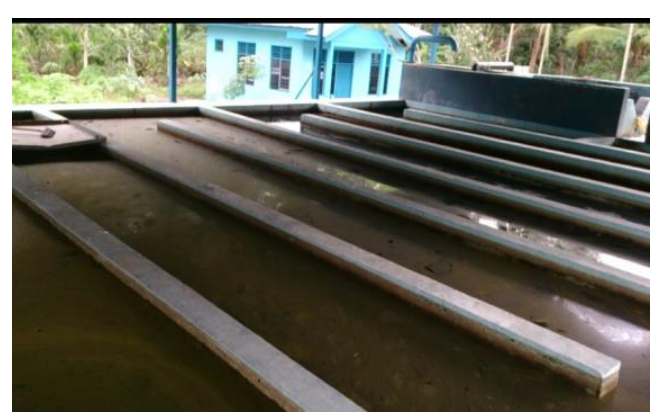

Gambar 5.8 Bak Flokulasi

(Dokumentai Lapangan)

\subsubsection{Bak Sedimentasi}

Proses pengolahan air untuk proses selanjutnya merupakan proses sedimentasi. Air yang telah mengalami proses flokulasi akan mengalir ke bak sedimentasi. Pada bak sedimentasi air akan diendapkan untuk memisahkan air dengan padatan dimana partikel flok akan mengendap karena pengaruh gravitasi. Didalam bak sedimentasi air disaring dengan menggunakan media saringan yang terbuat dari asbes.

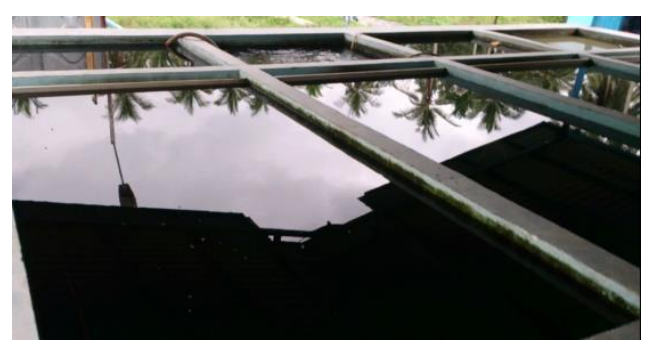

Gambar 5.9 Bak Sedimentasi

(Dokumentasi Lapangan)

Seharusnya pada bak sedimentasi ini proses perubahan air sudah nampak, kejernihan air sudah mulai nampak jelas pada proses sedimentasi ini, dikarenakan proses sebelumnya tidak sesuai maka hasilnya tidak maksimal. Berikut contoh hasil yang seharusnya terjadi.

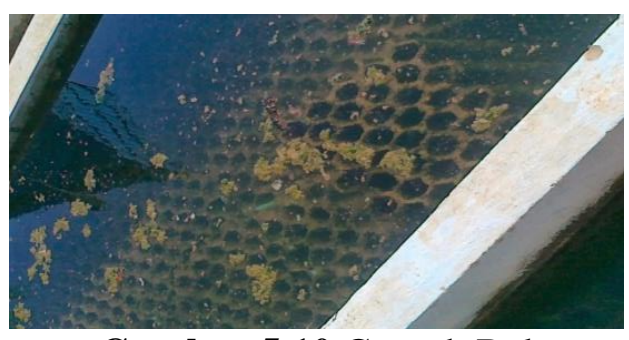

Gambar 5.10 Contoh Bak Sedimentasi (sumber internet)

\subsubsection{Bak Filtrasi}

Ini merupakan proses terakhir dari proses pengolahan air, Air yang telah mengalami proses sedimentasi merupakan air yang sudah bebas dari gumpalan-gumpalan kasar. Gumpalan halus yang tak bisa diendapkan pada bak sedimentasi akan diproses dalam bak filtrasi. Pada proses akhir filtrasi menggunakan kerikil dan batu kuarsa sebagai media filter agar kotoran halus yang tidak dapat mengendap dibak sedimentasi dapat disaring oleh 
media pasir sehingga air yang keluar dari bak benar-benar bersih.

\subsection{Reservoir}

Reservoir adalah bangunan atau bak yang fungsinya untuk menyimpan hasil akhir dari pengolahan. Setelah air melalui tahap-tahap pemerosesan maka air yang di alirkan menuju bak Reservoir, untuk bangunan Reservoir pada SPAM Kecamatan Rangsang terbuat dari Plat baja. Untuk kapasitas bangunan Reservoir ini mampu mampu menampung air berjumlah 500.000 liter. Untuk lebih jelasnya dapat dilihat pada gambar 5.8 .

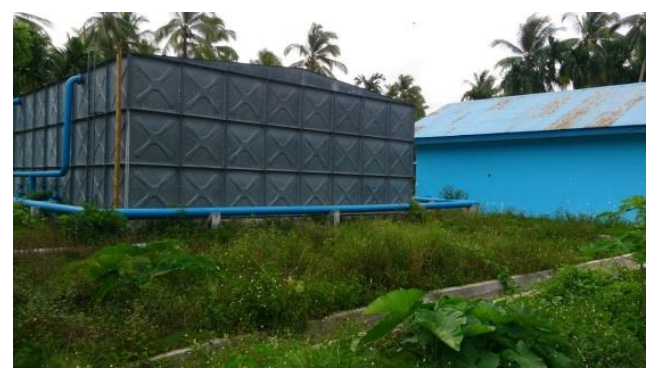

Gambar 5.11 bangunan bak Reservoir

(Dokumentasi Lapangan)

\subsection{Proses pengaliran ke Masyarakat}

Setelah bak Reservoir terisi dengan penuh, maka air siap untuk dialirkan ke masyarakat atau konsumen, untuk proses pengalirannya di bantu dengan menggunakan pompa distribusi, yaitu pompa jenis Sentrifugal. Pada SPAM Kecamatan Rangsang ini menggunakan 2 pompa distribusi, untuk kapasitas pengalirannya adalah 20 liter/detik dengan menggunakan pipa berukuran 4 inch dan 2 inch. Untuk saat ini hanya satu pompa saja yang beroperasi, dikarenakan pompa yang lainnya mengalami kerusakan, pihak
SPAM Kecamatan Rangsang belum melakukan perbaikan hingga saat ini.

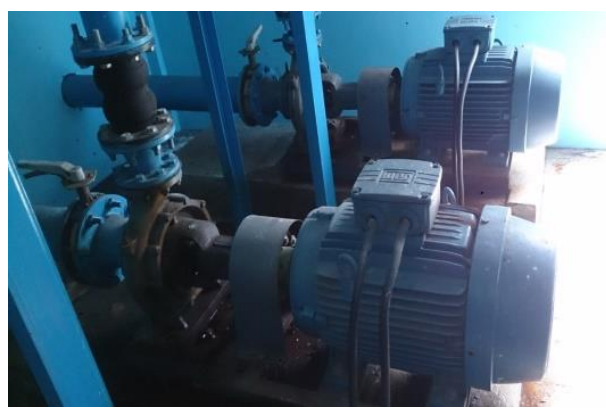

Gambar 5.12 Pompa distribusi jenis Sentrifugal

(Dokumentasi Lapangan)

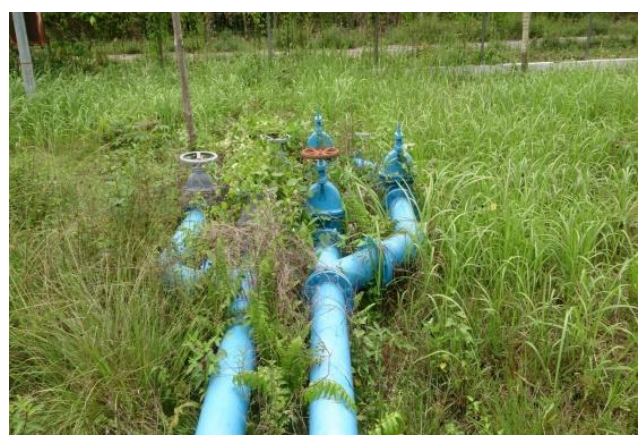

Gambar 5.13 Pipa Distribusi

(Dokumentasi Lapangan)

\subsection{Kualitas air bersih SPAM Kecamatan Rangsang}

Pemeriksaan air yang diproduksi oleh SPAM Kecamatan Rangsang dilakukan oleh petugas laboratorium SPAM Kecamatan Rangsang dengan cara memeriksa sampel air yang diproduksi sebelum didistribusikan kepada masyarakat. Hal ini dilakukan bertujuan agar air yang didistribusikan kepada masyarakat layak untuk digunakan dan telah memenuhi standar air bersih yang telah ditetapkan oleh Menteri Kesehatan Republik Indonesia. Untuk saat ini hasil kualitas air pada SPAM Kecamatan Rangsang hanya dilakukan pemeriksaan pada tahun 
2009 dan air tersebut layak dikatakan sebagai air bersih, tetapi setelah beberapa tahun kemudian tidak ada dilakukan pengujian laboratorium kembali. Sebagai peneliti dikarenakan 8 tahun terakhir tidak adanya hasil laboratorium terbaru maka peneliti melakukan uji laboratorium dengan membawa sampel pengolahan hasil akhir ke laboratorium Dinas Kesehatan Pekanbaru UPTD Laboratorium Pemeriksaan Kualitas Air dengan sampel satu liter hasil akhir pengolahannya.

Berikut adalah kualitas air saat ini yang dihasilkan oleh SPAM Kecamatan Rangsang dengan peraturan menteri kesehatan nomor 416 tahun 1990 tentang standar kualitas air bersih.

Dilihat dari hasil laboratorium dapat di simpulkan bahwa air SPAM Kecamatan Rangsang ini tidak layak untuk digunakan berdasarkan pada peraturan Menteri Kesehatan Republik Indonesia nomor 416 tahun 1990 tentang "syarat-syarat dan pengawasan kualitas air" yaitu mengenai standar kualitas air bersih. Untuk hasilnya dapat terlihat dari hasil laboratorium yang dilakukan pada tanggal 13 November 2017, untuk parameternya melebihi kadar maksimum standar parameter air bersih yang ditentukan.

Untuk perbandingan hasil

laboratorium pada tahun 2009 dan
Tabel 5.1 laporan hasil uji laboratorium (Dinas Kesehatan Pekanbaru, 2017)

\begin{tabular}{|c|c|c|c|c|}
\hline No & Parameter & Satuan & $\begin{array}{c}\text { Hasil } \\
\text { Uji }\end{array}$ & $\begin{array}{l}\text { Standar Baku Mutu } \\
\text { (kadar maksimum) }\end{array}$ \\
\hline 1 & 2 & 3 & 4 & 5 \\
\hline & A. FISIKA & & & \\
\hline 1 & Bau & - & Tidak Berbau & Tidak Berbau \\
\hline 2 & Kekeruhan & $\begin{array}{l}\text { Skala } \\
\text { NTU }\end{array}$ & 5 & 25 \\
\hline 3 & Rasa & - & Asam & Tidak Berasa \\
\hline 4 & Suhu & ${ }^{0} \mathrm{C}$ & 27,3 & Suhu Udara $+3^{\circ} \mathrm{C}$ \\
\hline 5 & Warna & $\begin{array}{l}\text { Skala } \\
\text { TCU }\end{array}$ & 372 & 50 \\
\hline 6 & \begin{tabular}{|l|}
$\begin{array}{l}\text { Jumlah Zat Padat } \\
\text { (TDS) }\end{array}$ \\
\end{tabular} & $\mathrm{mg} / \mathrm{l}$ & 116 & 1500 \\
\hline B & KIMIA & & & \\
\hline & a. Kimia Anorganik & & & \\
\hline 1 & Besi & $\mathrm{mg} / \mathrm{l}$ & 0,414 & 1 \\
\hline 2 & Kesadahan $(\mathrm{CaCO} 3)$ & $\mathrm{mg} / \mathrm{l}$ & 7,1 & 500 \\
\hline 3 & Khlorida & $\mathrm{mg} / \mathrm{l}$ & 1,51 & 600 \\
\hline 4 & Kromium Valensi & $\mathrm{mg} / \mathrm{l}$ & 0,04 & 0,05 \\
\hline 5 & Mangan & $\mathrm{mg} / \mathrm{l}$ & 0,138 & 0,5 \\
\hline 6 & Nitrat Sebagai N & $\mathrm{mg} / \mathrm{l}$ & 0,11 & 10 \\
\hline 7 & Nitrit Sebagai N & $\mathrm{mg} / \mathrm{l}$ & 0,03 & 1 \\
\hline 8 & $\mathrm{Ph}$ & $\mathrm{mg} / \mathrm{l}$ & 3,8 & $6,5-9,0$ \\
\hline 9 & Sulfat & $\mathrm{mg} / \mathrm{l}$ & 32,21 & 400 \\
\hline & b.Kimia Organik & & & \\
\hline 1 & $\begin{array}{l}\text { Zat Organik Sebagai } \\
\text { KMn04 }\end{array}$ & $\mathrm{mg} / \mathrm{l}$ & 15,62 & 10 \\
\hline & c. Mikrobiologi & & & \\
\hline 1 & $\begin{array}{l}\text { Total Bakteri } \\
\text { Koliform }\end{array}$ & $\begin{array}{c}\mathrm{jlh} / 100 \mathrm{~m} \\
\mathrm{l}\end{array}$ & 109 & 50 \\
\hline
\end{tabular}

hasil laboratorium pada tahun 2017 dapat dilihat pada tabel 5.2

Tabel 5.2 Perbandingan hasil uji laboratorium Dinas Kesehatan Pekanbaru dan SPAM Kecamatan Rangsang. 


\begin{tabular}{|c|c|c|c|c|c|}
\hline No & Parameter & Satuan & $\begin{array}{l}\text { Hasil Uji } \\
2009\end{array}$ & $\begin{array}{c}\text { Hasil Uji } \\
2017\end{array}$ & $\begin{array}{l}\text { Standar Baku Mutu } \\
\text { (kadar Maksimum) }\end{array}$ \\
\hline & A.FISIKA & & & & \\
\hline 1 & Bau & . & $\begin{array}{l}\text { Tidak } \\
\text { Berbau }\end{array}$ & $\begin{array}{l}\text { Tidak } \\
\text { Berbau }\end{array}$ & Tidak Berbau \\
\hline 2 & Kekeruhan & $\begin{array}{l}\text { Skala } \\
\text { NTU }\end{array}$ & 1 & 5 & 25 \\
\hline 3 & Rasa & . & $\begin{array}{l}\text { Tidak } \\
\text { Berasa }\end{array}$ & Asam & Tidak Berasa \\
\hline 4 & Suhu & ${ }^{\circ} \mathrm{C}$ & 24,4 & 27,3 & Suhu Udara $+3^{\circ} \mathrm{C}$ \\
\hline 5 & Warna & $\begin{array}{l}\text { Skala } \\
\text { TCU }\end{array}$ & 3 & 372 & 50 \\
\hline 6 & $\begin{array}{l}\text { Jumlah Zat Padat } \\
\text { (TDS) }\end{array}$ & $\mathrm{mg} / \mathrm{l}$ & 305 & 116 & 1500 \\
\hline & B.KIMIA & & & & \\
\hline & $\begin{array}{l}\text { D.Mimia } \\
\text { a.Knorganik }\end{array}$ & & & & \\
\hline 1 & Besi & $\mathrm{mg} / \mathrm{l}$ & 0,8050 & 0,414 & 1 \\
\hline 2 & $\begin{array}{l}\text { Kesadahan } \\
(\mathrm{CaCO} 3)\end{array}$ & $\mathrm{mg} / \mathrm{l}$ & 52 & 7,1 & 500 \\
\hline 3 & Khlorida & $\mathrm{mg} / \mathrm{l}$ & 43,54 & 1,51 & 600 \\
\hline 4 & Kromium Valensi & $\mathrm{mg} / \mathrm{l}$ & 0,0091 & 0,04 & 0,05 \\
\hline 5 & Mangan & $\mathrm{mg} / \mathrm{l}$ & 0,0191 & 0,138 & 0,5 \\
\hline 6 & Nitrat Sebagai N & $\mathrm{mg} / \mathrm{l}$ & 0,2875 & 0,11 & 10 \\
\hline 7 & Nitrit Sebagai N & $\mathrm{mg} / \mathrm{l}$ & 0,03 & 0,03 & 1 \\
\hline 8 & $\mathrm{Ph}$ & $\mathrm{mg} / \mathrm{l}$ & 6,83 & 3,8 & $6,5-9,0$ \\
\hline 9 & Sulfat & $\mathrm{mg} / \mathrm{l}$ & 122,44 & 32,21 & 400 \\
\hline & b.Kimia Organik & & & & \\
\hline 1 & $\begin{array}{l}\text { Zat Organik } \\
\text { Sebagai KMn04 }\end{array}$ & $\mathrm{mg} / \mathrm{l}$ & - & 15,62 & 10 \\
\hline & c. Mikrobiologi & & & & \\
\hline 1 & $\begin{array}{l}\text { Total Bakteri } \\
\text { Koliform }\end{array}$ & $\begin{array}{c}\mathrm{j} \mathrm{jh} / 100 \\
\mathrm{ml}\end{array}$ & - & 109 & 50 \\
\hline
\end{tabular}

Dilihat dari hasil laboratorium 2009 dan 2017 didapat hasil uji yang tidak melebihi kadar maksimum adalah hasil laboratorium pada tahun 2009, dilihat dari hasil uji pada tanggal 13 November 2017 untuk parameter yang tidak sesuai dengan standar baku mutu adalah :

\section{Rasa}

untuk rasa yang dihasilkan adalah asam, untuk standarnya tidak berasa.

2. Warna.

Untuk warna yang dihasilkan adalah 372 TCU, untuk kadar maksimum yang diperbolehkan adalah 50 TCU.

3. $\mathrm{Ph}$,

Untuk Ph air yang dihasilkan adalah 3,8 mg/l, untuk standar yang diperbolehkan antara 6,5-9,0 mg/l.

4. Zat Organik Sebagai KMn04 Untuk Zat Organik Sebagai KMn04 yang dihasilkan adalah 15,62 mg/l, untuk kadar maksimum yang diperbolehkan adalah 10 $\mathrm{mg} / \mathrm{l}$.
5. Total Bakteri Koliform, Untuk total bakteri koliform yang dihasilkan adalah $109 \mathrm{jlh} / 100 \mathrm{ml}$, unuk kadar maksimun yang diperbolehkan adalah $50 \mathrm{jlh} / 100 \mathrm{ml}$.

6. Suhu

Untuk suhu air yang dihasilkan adalah $27,3^{\circ} \mathrm{C}$, untuk standar yang diperbolehkan adalah $\pm 3^{0} \mathrm{C}$.

Maka dari hasil tersebut kondisi air hasil pengolahan saat ini berdasarkan hasil laboratorium (13 November 2017) pada SPAM Kecamatan Rangsang tidak memenuhi persyaratan air bersih, hal tersebut dikarenakan proses pengolahan tidak berjalan dengan sempurna, yaitu tidak adanya pembubuhan zat Koagulan dikarenakan zat Koagulan tidak ada untuk saat ini. Dilihat dari hasil uji laboratorium kondisi air SPAM Kecamatan Rangsang pada tahun 2009 juga tidak dapat dikatakan air bersih dikarenakan untuk parameter Suhu Air yang dihasilkan adalah $24,4^{\circ} \mathrm{C}$, hasil ujinya melebihi angka standar baku mutu air bersih yaitu $\pm 3^{0} \mathrm{C}$. Untuk saat ini masyarakat menggunakan air pengolahan SPAM Kecamatan Rangsang untuk keperluan seperti keperluan mencuci pakaian, peralatan makan, dan mandi. Berikut adalah gambar dari hasil pengolahan terdahulu dengan hasil pengolahan sekarang.

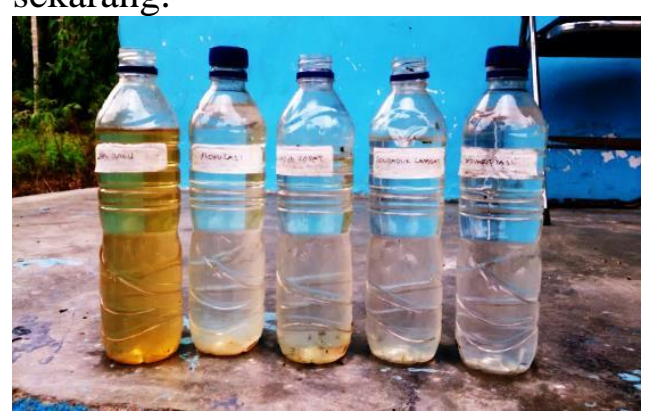

Gambar 5.14 Hasil pengolahan terdahulu

(Dokumentasi Lapangan) 


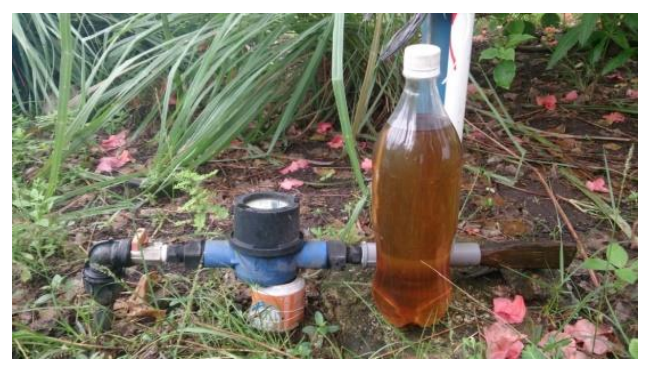

Gambar 5.15 Hasil pengolahan sekarang

(Dokumentasi Lapangan)

\section{KESIMPULAN DAN SARAN Kesimpulan}

Berdasarkan penelitian yang telah dilakukan di SPAM Kecamatan Rangsang Kabupaten Kepulauan Meranti maka dapat diambil beberapa kesimpulan sebagai berikut.

1. Pengolahan Air bersih pada SPAM Kecamatan Rangsang Kabupaten Kepulauan Meranti dimulai dari Penyadapan air baku (Raw Water) yang dialirkan ke Instalasi pengolahan Air (IPA) menggunakan satu unit pompa intake kemudian rumah kimia yang telah menyiapkan zat koagulan berupa Alumunium Sulfate

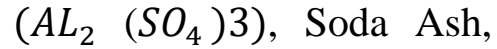
Kaporit dan polimer yang sudah diaduk dengan 1000 liter air lalu diinjeksi ke bangunan pengolahan air sehingga bercampur dengan air baku yang juga diinjeksi kebangunan pengolahan air, selanjutnya air yang telah tercampur dengan zat koagulan akan mengalami flokulasi pada bak flokulasi, kemudian air akan mengalir terus pada bak sedimentasi, pada bak ini air diendapkan sehingga air terpisah dengan partikel-partikel flok dengan menggunakan bahan seperti asbes lalu selanjutnya air mengalir ke bak filtrasi untuk memisahkan partikel padat dan cair dengan menggunakan bahan pasir, setelah melalui tahap filtasi selanjutnya air dialirkan ke reservoir dan air siap untuk didistribusikan kepada masyarakat.

2. Pada SPAM Kecamatan Rangsang terdapat beberapa masalah, yaitu tidak tersedianya bahan campuran zat-zat koagulan atau bahan kimia dan rusaknya 1 pompa Intake dan 1 pompa distribusi. terdapat 2 pompa Intake dan 2 pompa distribusi pada SPAM Kecamatan Rangsang, pada saat ini hanya 1 pompa Intake dan 1 pompa distribusi yang beroperasi.

3. Hasil pengolahan air bersih pada SPAM Kecamatan Rangsang ditinjau dari hasil uji Laboratorium pada tanggal 13 Novembar 2017 air yang dihasilkan tidak memenuhi standar kualitas air bersih berdasarkan standar air bersih yang ditetapkan Menteri Kesehatan nomor 416 tahun 1990 tentang "syarat-syarat dan pengawasan kualitas air". Pada tahun 2009 air hasil pengolahannya juga tidak masuk dalam kategori air bersih.

\subsection{Saran}

Setelah mendapatkan hasil dari pembahasan dan menyimpulkannya maka dapat 
diberikan beberapa saran sebagai berikut ini.

1. SPAM Kecamatan Rangsang Kabupaten Kepulauan Meranti selaku pengelola air bersih di Kecamatan Rangsang sebaikanya dapat mengoptimalkan kinerja pengolahan air, yaitu mengenai pembubuhan zat Koagulan, sebaiknya segera untuk memenuhi kebutuhan zat Koagulan tersebut supaya proses pengolahan berjalan dengan sempurna.

2. Bagi penelitian selanjutnya dilakukan penelitian yang menyangkut dengan sitem pendistibusian air bersih kepada masyarakat.

\section{DAFTAR PUSTAKA}

Anonymous, Air Tanah

(https://id.wikipedia.org/wiki/ Air tanah), diakses Tanggal 18 Juli 2017

Asdak, 2006. "Permberdayaan sumber daya air" Tri Media. Jakarta

Juliana, 2016 "Tinjauan proses pengolahan Air Baku (Raw water) menjadi air bersih pada BPAB Rambah Hilir Kabupaten Rokan Hulu”.

Saputri, Afrike Wahyuni, 2011. "Evaluasi Instalasi Pengolahan Air Minum (IPA) Babakan PDAM Tirta Kerta Raharja Kota Tangerang"

Sembiring, Deddy H, 2014. "Ptoses pengolahan air baku menjadi air bersih pada PDAM Tirtanadi IPA Deli tua”.
Silalahi, 1996. Pengantar Hukum Dan Sumbar Daya Air di Indonesia. IKAPI. Bandung

Soemarto, 1987 Hidrologi Teknik. Usaha Nasional. Surabaya
Sutrisno, dkk, Penyediaan Air Bersih. Rineka Cipta. Jakarta

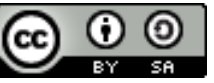

This is an open access article which means that all content is freely available without charge to the user or his/her institution. Jurnal Saintis allows the author(s) to hold the copyright without restriction. The copyright in the text of individual articles (including research articles, opinion articles, and abstracts) is the property of their respective authors distributed under the terms of the Creative Commons Attribution-ShareAlike 4.0 International License(https://creativecommons.org/licenses/by-sa/4.0/) which permits unrestricted use, distribution, and reproduction in any medium. Users are allowed to read, download, copy, distribute, search, or link to full-text articles in this journal without asking by giving appropriate credit, provide a link to the license, and indicate if changes were made. 